\title{
EMBRAER: From national champion to global player
}

\section{Andrea Goldstein}

OECD Development Centre, Paris, France

andrea.goldstein@oecd.org
Much has been written on the macroeconomic aspects of the economic reform process in Latin America, but much less has been published on its microeconomic results, especially at the company level. This paper explores how Embraer, a Brazilian aircraft manufacturer, transformed itself after privatization to become a world market leader in a hightech industry traditionally dominated by companies based in member countries of the Organization for Economic Cooperation and Development (OECD). Its main findings are that top management played a key role in aligning innovation for dynamic capabilites, that the company has been very successful in forming alliances with foreign partners and strengthening its bargaining position, and that the Brazilian authorities have consistently supported Embraer after relinquishing direct control. For these results to be extended to other companies, however, Brazil's export promotion tools must be made compatible with multilateral norms. 


\author{
"We are engineering minded [...], \\ not fanatical about the business side" \\ Juarez Wanderley, President of embraer \\ Financial Times, 6 June 1995 \\ “EMBRAER's aircraft are developed \\ with customer satisfaction in mind" \\ Mauricio Botelho, President of embraer \\ InfoBrazil, 26 May 2000
}

\section{I}

\section{Introduction}

Large industrial enterprises have historically played a vital role in developing new technologies, marketing new products, and introducing new organizational forms (Chandler, Amatori and Hikino, 1997). In this way, they have contributed to economic growth and development in Europe, North America, and East Asia, although of course they may have also generated inefficiencies, especially through their ability to lobby for wrong policies (Goldberg and Maggi, 1999). What is conspicuous about Latin America is the region's inability to nurture big firms, especially if they are private-owned and/or export-oriented. There are of course more than a few relatively large private diversified groups -indeed, they constitute the backbone of the business community in most developing countries - but they mostly cater for the domestic market and are hardly market leaders in their lines of business. And there are also some large exporters, which may sometimes even claim a large share of the world market for their goods, but these are mostly State-owned concerns exploiting non-renewable mineral resources such as oil and copper.

One of the few Latin American manufacturing companies that can justifiably claim to be a world leader in its market is Brazil's Embraer, which vies with Bombardier for the third place in the world ranking of

I am grateful to Roberto Carlos Bernardes, Takahiro Fujimoto, and various executives of Embraer for conversations on the subject matter of this paper and to Edmund Amman, Steve McGuire, Richard Moxon, Nelson Silva and Paulo Bastos Tigre, as well as the participants in the seminars of the Center for Brazilian Studies (Oxford), INSEAD, the National University of Singapore and three anonymous referees, for their comments and suggestions. The usual disclaimers apply: in particular, the opinions expressed do not reflect the position of the OECD, the OECD Development Centre, or the organization's member States. aircraft manufacturers - and is more profitable than its Canadian arch-rival. In this industry, success depends on sound design and manufacturing strength, ${ }^{1}$ the price and operational costs of the aircraft, and the after-sales services provided to customers, who are relatively few in number but are spread around the world. Launch and research and development (R\&D) costs, as well as survival risk, are high, but cost reductions over time from learning by doing are unusually large. In short, this is a global oligopolistic sector, where, not surprisingly, almost all the countries now offering world-class planes were already established in aviation by the end of World War I.

The purposes of this paper are two-fold. First, to add to the literature on the results of privatization by exploring the continuity in Embraer's corporate history and determining to what extent the resources, skills and learning capabilities that have proved crucial in gaining market shares on world markets in the 1990s had been accumulated under public ownership and how the transfer of ownership has made it possible to turn them into sources of competitive advantage. Second, to contribute to the literature on the forms of State intervention supporting industrial transformation by looking at a concrete example in a high-tech industry (Embraer) to find out how this company interacts with the Brazilian government apparatus and the global economy, whether a successful Latin American

\footnotetext{
${ }^{1}$ The actual manufacture of an aircraft consists of three principal stages: i) fabrication of primary parts (metal sheets and plates, parts produced using computerized and non-computerized machines, and prefabricated parts); ii) assembly of major components, and iii) final installation of the aircraft's various operating systems (such as wiring and electronics) in the structure.
} 
company like this is any different from its competitors in more advanced industrial countries, and to what extent its dynamics can be successfully replicated in other industries and/or countries.

Having stated what this paper is about, it is equally important to specify what it is not about. First, it does not test quantitatively whether public intervention has been successful domestically, i.e., whether the benefits outweighed the costs, and internationally, i.e., whether that intervention served to increase competition in the world market for regional jets. ${ }^{2}$ Second, and related with the foregoing, it does not seek to explain the circumstances in which governments support a domestic industry up to the point of risking external retaliation. The literature on strategic trade policy does both these things, using two separate approaches. As far as modeling is concerned, it would be interesting to update the results of Baldwin and Flam (1989), who included Embraer in a 3-country study of the market for 30-40 seat commuter aircraft; as far as political science is concerned, Goldstein and McGuire (2002) analyse Embraer in parallel with its Canadian rival, using the framework developed in Busch (1999).

The next two sections present the history of the company, first as a State-owned entity (section II) and then in the period following privatization (section III), with the aim of identifying the specific focuses of business competence accounting for the rise of Embraer in the 1970s and 1980s, the reasons why difficulties subsequently arose, and the elements of continuity and change since 1994. These factors are then analysed in section IV, while the conclusions (section V) link this case study to the wider debate on the results of privatization, the role of the State in nurturing industrial transformation, and the contribution of large industrial enterprises to this process.

\section{II}

\section{EMBRAER as a State-owned enterprise: 1969-1994}

\section{The origins}

The Brazilian armed forces have had an active and ongoing interest in industrialization since the $19^{\text {th }}$ century, and an industrialist-technocratic orientation developed within them in the 1940s (Sikkink, 1991). Influential military thinkers, such as General Carlos de Meira Mattos, developed a geostrategic theory of Brazil's place in the world system predicated on the country's success in achieving technological and industrial autonomy. As regards the aeronautical sector, concrete strategies involved a market reserve policy, State financing, and technological support to private firms through the Centro Tecnológico Aerospacial (Aerospace Technology Centre) (CTA), ${ }^{3}$ established in

\footnotetext{
${ }^{2}$ In 1991 the European Union blocked the takeover of De Havilland by the Franco-Italian ATR consortium on the grounds that the merged firm would have dominated the turbo-prop aircraft market. Bombardier eventually bought up its smaller Canadian rival. A formal analysis of the market for regional jets, which ATR has not entered, could determine whether Brazilian export subsidies, insofar as they prevented Bombardier from acquiring monopoly power, have increased consumer welfare.

${ }^{3}$ In 1971 the CTA changed its name to Centro Técnico Aeroespacial (Technical Centre for Aerospace Activities).
}

1945 at São José dos Campos, in the state of São Paulo, because of the availability of electrical power, a pleasant climate, and excellent topography (Campolina Diniz and Razavi, 1999). The CTA, an umbrella organization for aeronautical research modeled on the Massachusetts Institute of Technology, grew to become "probably the most advanced research [institution] among industrializing countries" (Dahlman and Frischtak, 1993, p. 437), and led to the establishment of sister institutions devoted to technical training (Instituto Tecnológico da Aeronáutica (Institute of Aeronautical Technology) (ITA)) and aerospace research (Instituto de Pesquisas Espaciais, INPE).

Various prototypes were built and some, such as the Paulistinha, entered into production. In the early 1960s the Brazilian economy ran out of steam and the ensuing deterioration in political stability eventually led to a coup in 1964 and to 21 years of military rule. While they fully accepted private ownership, the military directed greater efforts towards development planning and increased resources were allocated to science and technology. For reasons of national security, it was argued, Brazil could not afford to depend on imported aircraft and spare parts, nor could it allow the domestic manufacture of such strategic equipment to 
be controlled by foreign companies. A revival of the alliance between public sector technicians and the military, which had been so important for the founding of State-owned enterprises in the 1940s and 1950s (Trebat, 1983), led to the creation of Embraer (Empresa Brasileira de Aeronautica - Brazilian Aeronautical Corporation) in $1969 .{ }^{4}$ Embraer was majority-owned by the government and inherited some mission-oriented activities from the CTA, especially the IPD-6504 project to produce a prototype of a twin-engine turbo-prop plane. Although the relationship between the company and the Ministry of Aeronautics remained very close, much bureaucratic red tape was avoided and a clear sense of corporate mission emerged. ${ }^{5}$ Not only did the Ministry manipulate the domestic market to Embraer's advantage, ${ }^{6}$ but it also concentrated in its hands most financial, fiscal, marketing, regulatory, and international responsibilities, which were transferred to Embraer. In addition, the firm was able to provide customers with alternate financing through BNDES (a State development bank), it benefited from FINEX (Fundo de Financiamento à Exportação - Export Finance Fund), an export support scheme administered by Banco do Brasil, and it was granted very generous tax holidays. ${ }^{7}$ Finally, in 1973 the Ministry of Foreign Affairs set up PNEMEM (Política Nacional de Exportação de Material

\footnotetext{
${ }^{4}$ Other important defence companies in São José dos Campos which also spun off from CTA are Avibras (established in 1961) for the production of missiles and Engesa (set up in 1975) for the manufacture of tanks and armoured vehicles. In the 1980s, Avibras sold an estimated 66 Astros II multiple rocket launchers to Iraq and an unspecified number to Saudi Arabia, Bahrain, and Qatar. Total sales of the Astros II between 1982 and 1987 reached US\$ 1 billion. While Avibras has been highly dependent on imported components, Engesa developed its own design and technology capabilities and was more integrated with the local industrial base, especially auto parts manufacturers. See Brazil Special Weapons Guide at http://www.fas.org/nuke/guide/brazil/index.html.

${ }^{5}$ The composition of the board of directors remained the same between 1969 and 1986 (Silva, 1998, p. 567).

${ }^{6}$ The government and the Brazilian Armed Forces bought roughly a third of the Bandeirantes produced before 1980. They usually paid up-front and directly contributed to development expenditures. ${ }^{7}$ All weapons-producing companies were exempted from duties on the import of inputs. Moreover, Embraer did not pay trade (ICM) and production (IPI) taxes. Furthermore, all Brazilian companies buying non-voting shares in Embraer could obtain a 1\% rebate on corporate income tax. Federal agencies were also required to buy Brazilian aircraft provided their price was not more than $15 \%$ higher than that of competing imported goods. Finally, aircraft imports were subject to a $50 \%$ duty if a competing Brazilian product was available.
}

de Emprego Militar - National Military Materiel Export Policy), an ad hoc program to promote arms exports.

\section{The rise}

Production started in the 1970 s in co-operation with foreign partners, under co-production and licensing arrangements designed to achieve rapid market penetration without excessive technological dependence. The need to limit the degree of vertical integration was recognized early on as a key imperative, in order to avoid the risk of excessive fragmentation of business operations that had doomed previous attempts at manufacturing aircraft in Brazil (Silva, 1998, p. 177). ${ }^{8}$ For the most part, Embraer shied away from manufacturing high-value, high-technology components and concentrated instead on designing the aircraft, producing fuselages, and assembling the final product: already in the 1970 s it signed long-term purchase agreements with its major suppliers. Its two best-selling planes - the two-seat Tucano turbo-prop military trainer and the 19-seat non-pressurized twinengine turbo-prop Bandeirante - were of national design, although more than half of the latter's value consisted of imported parts. Particularly fruitful collaboration with Italian partners led to the production of the Xavante jet trainer and ground-attack plane (under license from Aermacchi) and of the AMX (in joint venture with Aeritalia and Aermacchi), a subsonic (Mach 0.86) ground-attack aircraft for battlefield interdiction, close air support, and reconnaissance missions. Embraer also used the threat of a steep increase in import duties to successfully arm-twist foreign producers of general aviation aircraft into accepting an agreement whereby they had to provide the kits to assemble the final product in Brazil. Piper, which accepted this offer, increased its market share dramatically at the expense of its competitors, Beech and Cessna. Besides technical competence, all these partners provided Embraer with organizational knowhow in series production. ${ }^{9}$ Within the Grupo Permanente

\footnotetext{
${ }^{8}$ Insofar as poaching qualified staff from CTA/ITA reduced these institutions' pool of technical skills, however, Embraer paradoxically ended up with excessive internalization of R\&D activities (Dagnino, 1993, p. 15).

${ }^{9}$ Since the 1980s Embraer has been the sole subcontractor for the design and production of outboard flaps for the McDonnell Douglas MD-11, as well as for the production of the tail fin and wing tips for the Boeing 777. It also manufactures precision-machined parts for the 747 and 767 .
} 
de Mobilização Industrial (Standing Industrial Mobilization Group), which had brought together the Armed Forces and the Federation of São Paulo Industries since 1965, Embraer also developed close collaboration with Brazilian private firms, which supplied an increasing share of the final components. Half of Embraer's directors were also private sector executives (Silva, 1998, p. 256). Although equity links were relatively tenuous, aeronautics could thus be seen as a good example of the "triple alliance" between multinational corporations, local private entrepreneurs and State-owned enterprises which accounted for Brazil's rapid capital accumulation up to the early 1980s (Evans, 1979).

A strong focus on the export market was another priority set from the very beginning and proved crucial in offsetting development costs. It permitted longer production runs, stimulated customers to bring new ideas for technical change, and demanded exacting performance standards. In order to be certified on all major markets, Embraer's products included backup systems for major functions and appropriate safety margins for structural components. But the company correctly saw a niche for aircraft that could operate in the more difficult environment (harsh weather conditions, unprepared or unpaved airstrips, minimum ground support) of backward regions and countries and were easier and cheaper to maintain. ${ }^{10}$ The Bandeirante joined the fleets of a number of commuter airlines in the United States, accounting by 1982 for a third of the market for 10-20 seat commuters at the expense of American manufacturers (Dagnino, 1993, p. 9). ${ }^{11}$ As they lacked finance and the capabilities to design a competitive product, rivals such as Beech and Fairchild were unable to respond to the introduction of the Bandeirante. The same logic was behind the production of military aircraft that were less sophisticated than those exported by advanced industrial countries. Thus, the Tucano, which combined low cost and innovative technical solutions (e.g., ejection seats and tandem pupil-trainer alignment), was sold to the British and French air forces and produced in Egypt under license. The net foreign exchange impact, however, was minor

\footnotetext{
${ }^{10}$ While turboprops are less powerful than straight jets, they have wider wings and therefore require shorter runways. They also consume less fuel.

11 Since brand recognition is an important aspect in the aircraft market, Embraer faced a huge initial obstacle because its name was unknown to travellers — and faith in a Brazilian-made plane was also very low (Silva, 1998, p. 375).
}

and spillovers, if any, never reached a critical level, not least because of the obstacles to labour mobility posed by the dual nature (civil and military) of the technology developed and used by Embraer's technicians (Frischtak, 1992).

\section{The crisis}

While the debt crisis ended the period of low finance costs that had supported the rise of the Brazilian aerospace industry, the time of reckoning did not arrive for Embraer until the early 1990s. True, as the post1982 economic crisis took its toll on Brazilian corporations, drastically reducing their profits and therefore their tax commitments, the mechanism designed to provide private equity finance to Embraer dried up and the government's stake in its ownership increased accordingly. Even so, in the peculiar framework of the post-1985 Brazilian democratic transition, the air force heads successfully resisted the cancellation of ministerial status and managed to protect the corresponding budget appropriation from the calls for fiscal discipline emanating from the Finance Ministry and the Bretton Woods institutions (Solingen, 1998). ${ }^{12}$

The EMB-120 Brasília, a 30-seat pressurized turboprop derived from the Bandeirante, was launched in 1985 and was supposed to become the firm's main aircraft. ${ }^{13}$ To design and produce this new plane, considerable investment was made in the areas of metalto-metal bonding, chemical milling, and composite materials manufacturing (Frischtak, 1992). Thanks to its low operating costs, high dispatchability, and relatively high cruising speed, the Brasília met with initial success, capturing a third of the total market for 30-40 seat commuters (Baldwin and Flam, 1989, Table 1, p. 493). ${ }^{14}$ The world recession in the late $1980 \mathrm{~s}$ and the Brazilian government's decision to discontinue FINEX, however, hit Embraer. Furthermore, the

\footnotetext{
12 In 1998, President Cardoso finally managed to set up a unified Defence Ministry headed by a civilian, in place of separate ministries run by each service: a change that had happened a decade or so earlier in the rest of South America.

${ }^{13}$ The Xingu executive plane, the first pressurized aircraft produced by Embraer, proved a commercial failure but allowed the company to accumulate knowledge later used in developing the Brasilia.

${ }^{14}$ Simulation experiments suggest that export subsidies proved effective in shifting profits to Embraer (Baldwin and Flam, 1989). In 1982, questioning the fairness of subsidies granted for exports of the Bandeirante, Fairchild filed an ultimately-rejected complaint before the US International Trade Commission.
} 
simultaneous attempt to develop a smaller derivate, the CBA-123, in cooperation with Argentina's Fábrica Militar de Aviones (FAMA) turned into a flop. While technically sophisticated, the plane was too expensive, not least because FAMA did not have the capacities required to cooperate with Embraer. Political motivations - to strengthen bilateral co-operation and build mutual trust with Argentina- primed over business considerations and, following the departure of Silva in 1986 to assume the presidency of Petrobras, Embraer could not resist them. Cash-flow management suffered: in an industry where long-term financing is indispensable to match extended development lead times, the company accumulated debt with a dangerously short time-profile. As explained by Frischtak (1992, p. 21), "the presence of specialized skills and endowments accumulated in the process of developing [the AMX and the Brasília...] presented Embraer's engineers with an 'opportunity' [to produce] an overdesigned [aircraft] (in the sense of not respecting market constraints: price)". Although Embraer had been able to build competitiveness and secure an important presence on overseas markets, the preeminence of engineering over marketing considerations does not surprise in view of the company's long-term reliance on public procurement. The military are customers who attach notoriously high importance to performance requirements, and indeed it was in the context of the AMX project that Embraer installed a $\mathrm{CAD} / \mathrm{CAM}$ computer-aided design system: the first company in Brazil to dispose of such technology (Sbragia and Terra, 1993, p. 3).

During the Collor and Franco administrations (1990-1994), political circumstances further hindered the launch of economic adjustment, privatization, and structural adjustment measures. The end of the IranIraq war, ${ }^{15}$ the lower intensity of the Angola conflict, and the more aggressive stance of the United States government in supporting American producers, closed export markets for Embraer's military equipment. As delays mounted and orders were cancelled, the cost of managing the inventory of unsold planes rose. Some of Embraer's specialized suppliers, such as Engesa and Tecnasa, went bankrupt and the unemployment rate in São José dos Campos reached a level twice as high as that of the state of São Paulo as a whole (Broinizi Pereira, 1991). ${ }^{16}$ Despite efforts to diversify into services and other activities, in 1994 Embraer made a loss of US\$ 310 million, with sales of only US\$ 177 million (table 1) and its place in the ranking of Brazil's largest exporters fell to $38^{\text {th }}$. The return of Silva in 1991 could do little to reverse this decline, although it may have proved crucial in accelerating the subsequent privatization.

\section{III}

\section{Embraer as a private company}

\section{The privatization operation}

Despite the opposition of the military and a long strike in 1990, the worsening economic situation led the government in January 1992 to include Embraer in the list of State-owned enterprises to be sold. Following six failed attempts, in December 1994 a consortium

\footnotetext{
${ }^{15}$ Nearly $40 \%$ of all Brazilian arms sales from 1985 to 1989 went to Iraq. Precise financial data on the importance of the Middle East market for Embraer are not available. The company received orders for the EMB-312 Tucano (110 from Egypt in 1983, 80 from Iraq in 1985, 50 from Iran in 1988, and 100 from Libya in 1986), the EMB111 marine patrol aircraft (two from Algeria in 1982 and eight from Libya in 1986), and the EMB-121 Xingu (25 from Libya in 1986).
}

bought a controlling $45 \%$ stake for US\$ 89 million. The syndicate included American investors assembled by Wasserstein Perella, a New York investment boutique; Bozano Simonsen, one of Brazil's greatest financial conglomerates; and Previ and Sistel, the pension funds of the Banco do Brasil and Telebrás,

\footnotetext{
${ }^{16}$ All Avibras programmes were put on hold in January 1990, when the company filed for bankruptcy. Its employee roster had fallen from 6,000 to 900 and the company had US\$ 90 million worth of unsold rockets. Avibras improved its financial health in the early 1990 s, and signed a deal with NASA in 1994 for the joint development of a rocket programme. Engesa has been dismembered, with some of its companies sold to private interests, and with ordnance-related firms taken over by the State and integrated with Imbel (Indústria de Material Bélico - War Materiel Industry).
} 
TABLE 1

Embraer: Main financial data

(in millions of US dollars) ${ }^{a}$

\begin{tabular}{|c|c|c|c|c|c|c|c|c|c|c|c|}
\hline & $\begin{array}{l}\text { Average } \\
1985-91\end{array}$ & 1992 & 1993 & 1994 & 1995 & 1996 & 1997 & 1998 & 1999 & 2000 & 2001 \\
\hline Gross revenues & 440 & 333 & 261 & 177 & 295 & 390 & 772 & 1,362 & 1,861 & 2,859 & 2,929 \\
\hline \multicolumn{12}{|l|}{ Of which (per cent) } \\
\hline Domestic market & 45 & 68 & 62 & 60 & 61 & 65 & 16 & 11 & 5 & 2 & 2 \\
\hline Export & 55 & 32 & 38 & 40 & 39 & 35 & 84 & 89 & 95 & 98 & 98 \\
\hline \multicolumn{12}{|l|}{ Of which (per cent) } \\
\hline Civil, incl. services & .. & .. & .. & .. &.. &.. & 88 & 84 & 94 & & 96 \\
\hline Defence & .. & .. &.. & .. &.. &.. & 12 & 16 & 6 & & 4 \\
\hline Net earnings & -62 & -258 & -116 & -310 & -253 & -122 & -31 & 114 & 227 & 353 & 467 \\
\hline Exports &.. & .. &.. & .. & 193 & 264 & 634 & 1,173 & 1,692 & 2,377 & 2,617 \\
\hline Imports & .. & .. &.. & .. & 147 & 220 & 469 & 881 & 1,178 & 1,249 & 1,723 \\
\hline Net balance & .. & .. & .. & .. & 46 & 44 & 165 & 292 & 514 & 1,128 & 894 \\
\hline Investment & .. & .. & .. & .. & 105 & 102 & 81 & 122 & 147 & & \\
\hline Research \& development & 117 & 24 & 35 & 55 & 53 & 75 & 72 & 146 & & & \\
\hline Number of employees & .. & .. & .. & 6,087 & 4,319 & 3,849 & 4,494 & 6,737 & 8,302 & 10,334 & 10,900 \\
\hline $\begin{array}{l}\text { Revenues per employee } \\
\text { (thousands of US dollars) }\end{array}$ & .. & .. &.. & 29 & 68 & 101 & 172 & 242 & 247 & 302 & 269 \\
\hline $\begin{array}{l}\text { Memorandum items } \\
\text { (millions of constant } \\
1996 \text { dollars) }\end{array}$ & & & & & & & & & & & \\
\hline Gross revenues & .. & 363 & 278 & 184 & 301 & 390 & 757 & 1,320 & 1,778 & 2,671 & 2,678 \\
\hline Exports & .. & .. & .. & .. & 197 & 264 & 622 & 1,137 & 1,617 & 2,221 & 2,393 \\
\hline Imports & .. & .. & .. & .. & 150 & 220 & 460 & 854 & 1,126 & 1,167 & 1,575 \\
\hline Research \& development & .. & 26 & 37 & 57 & 54 & 75 & 71 & 142 & .. & .. & .. \\
\hline
\end{tabular}

Source: Embraer and MDIC/SACEX (trade balance data; 2000 and 2001 figures are January-November).

a The amounts expressed in US dollars were obtained using the average or the final rate of exchange of the commercial dollar during the corresponding periods, depending upon whether they refer to the income statement or the balance sheet data, respectively.

respectively. ${ }^{17}$ The government injected new capital, assumed the debt (US\$ 700 million), and retained $6.8 \%$ of the company's stock, including a "golden share" carrying veto power over, among other things, change of control and corporate purpose and creation and alteration of defence programmes (regardless of whether or not the Brazilian government participates in such programmes). ${ }^{18}$ Clauses included in the

${ }^{17}$ In June 1995, after Wasserstein Perella's failure to pay the money it had pledged, Bozano Simonsen bought it out. Together, the three main shareholders account for $60 \%$ of Embraer's outstanding common stock.

${ }^{18}$ The government has the right to designate one board member and has customarily chosen an Air Force general for such position. Until 2001, a second board member, also a general, was elected by the controlling shareholders. In 2000, the then Minister of Foreign Affairs, Lampreia, argued that the government-appointed representative could be a civilian, possibly a diplomat. He himself was appointed to the board in January 2001 upon his retirement from the government. agreement limited foreign ownership to $40 \%$ and imposed a 6-month moratorium on layoffs.

The new owners hired an outside executive to chair the firm (although to this day three of the six executive vice-presidents are long-time Embraer executives), injected R\$ 413.6 million since 1996 to strengthen the company's equity base, and intensified efforts to improve the profile and conditions of its heavy debt burden. Production methods and processes were improved, including substantial investment in IT systems, leading in July 1997 to the award of ISO 9001 certification for quality in design, production, sales and service. A fully-owned finance company to help airlines to lease, rather than buy, new aircraft and trade in used ones was set up in the Cayman Islands. An international consultancy firm designed a new organizational chart, which instead of being built around strict functional specifications is structured around single projects to enhance flexibility, interaction, and autonomy.

Services such as site maintenance, transportation, catering, security and machinery upkeep were 
outsourced and, following the dismissal of 1,200 whitecollar employees and 500 engineers and workers in June 1995 (Bernardes, 2000a, p. 292), the payroll fell to 3,849 workers at the end of 1996. In May 1996 workers agreed to wage cuts and shorter, but more flexible, weekly working hours to match a $10 \%$ cut in management salaries. Productivity rose: between 1990 and 1996 the time needed to make a Brasília was reduced from 16 months to nine. ${ }^{19}$ Four overseas support centres were created and in June 1995, as the first sign of its renewed confidence, Embraer signed a risk-sharing agreement with United TechnologiesSikorsky for the development and production of the fuel system, fuel tanks and landing gear of the S-92 19-seat, twin-engine, turbine-powered civilian helicopter. This deal, which is projected to account for $10 \%$ of Embraer's sales revenues, gave the company access to important technological advances in the field of new materials (Invar) and virtual design (CATIA). ${ }^{20}$

\section{The recovery}

In 1989 Embraer decided to venture into what was then a niche market for jets plying regional routes - generally shorter than 1,000 kilometres and with an average travel time of approximately one hour- with a 50 -seater. The ERJ- $145^{21}$ project was stopped as the company sought new owners, but was accelerated after privatization as the new management deemed that the company's very survival hinged on its success. No one will be able to say for sure whether the leap into jet manufacturing was dictated by prestige motives -the desire of engineers to prove their ability at developing an even more sophisticated aircraft- or by careful attention to market signals. Market intelligence was only created as a formal corporate function in 1991. What is sure is that the development effort came as regional turbo-prop operators started upgrading to jets. As industry liberalization made major carriers increasingly dependent on the traffic generated outside major hubs, "feeder" carriers were pushed into extending the length of the "spokes" (the cities that are served by each hub)

\footnotetext{
19 "Embraer's Little Jet Could Circle the Globe", Business Week, 28 October 1996.

${ }^{20}$ Embraer uses CATIA (Computer Aided Three-Dimensional Interactive Application) as a standard geometric modeling platform to reengineer aircraft manufacturing development processes and improve integration of internal operations and relations with international partners.

${ }^{21}$ Embraer planes, which were originally designated as EMB, gained the ERJ suffix in late 1997.
}

and increasing the frequency of services. In addition, passengers started expressing a clear preference for jets, which are faster, more versatile, and cause less noise and vibration than turbo-props. The market for regional jets has thus grown by more than $50 \%$ between 1998 and 1999 and it is estimated that it will amount to at least US\$ 56 billion in the next decade (Financial Times, 2000). The already favourable prospects are made even rosier by the upcoming expiration of the $1980 \mathrm{~s}$ agreements between airlines and unions in the United States. These specified that "feeder" carriers would not use planes with more than 70 seats, as the pilots of the big airlines feared that if they did jobs would shift to these lower-cost affiliates.

The ERJ-145 is lighter, cheaper to buy, and $15 \%$ less expensive to operate than its main rival, Bombardier's CRJ-200 (which goes slightly farther and faster and was introduced a few years earlier). ${ }^{22}$ Its superior engineering performance partly results from the incorporation of the turbofan technology developed for the AMX programme, while its price competitiveness owes something to the fact that $30 \%$ of its components are shared with the Brasília (including the nose section and cabin), as well as to lower labour costs. The new plane was presented at the 1996 Farnborough fair and secured its first contract with Continental Express, a subsidiary of Continental Airlines. ${ }^{23}$ The $300^{\text {th }}$ ERJ-145 was delivered to British Regional Airlines in September 2000 , three years and eight months later. In comparison, it took almost seven years for Bombardier to deliver the same number of CRJ-200s. In 1998 the company rolled out the first prototype of the ERJ-135, a 37passenger version of the ERJ-145, with which it shares $96 \%$ of its parts, thus lowering development costs and making the smaller plane more attractive to operators already committed to its larger counterpart. ${ }^{24}$ Riding on this trend, Embraer returned to profitability in 1998 after 11 consecutive years in the red (table 1$).{ }^{25}$

\footnotetext{
${ }^{22}$ Nelson Silva, Managing Director, Embraer Europe, gave this information in a personal communication.

${ }^{23}$ The ERJ-145 is equipped with Rolls-Royce engines and with flight instruments, such as engine-indication instruments, crew-alert systems and digital flight control systems, produced by Honeywell. ${ }^{24}$ For instance, pilots need only to be trained on any aircraft within a family in order to be certified to fly all aircraft within that family, and the same ground support equipment can be utilized. A longrange version of the ERJ-145, operating on routes of up to 3,000 kilometres was also certified in 1998 and the first model of a 44seat jet, the ERJ-140, was delivered in July 2001 to American Eagle. ${ }^{25}$ Operating results have been positive since 1996.
} 
Employment has grown to over 10,000 people, and as the new workers are obviously younger and also increasingly female, the unionization rate has decreased substantially (from $48 \%$ to $28 \%$ between 1997 and 2000) (Embraer, 2000a, p. 79).

Exports now account for $90 \%$ of total sales and Embraer claims to lead unit sales in the world market for regional aircraft. The 1999 devaluation of the Brazilian real reduced the wage bill from $13 \%$ to $9.7 \%$ of production costs between 1997 and 1999 (Embraer, 2000a, p. 43), but at the same time it increased the financial costs of raising new debt, as well as servicing outstanding dollar-denominated liabilities, and reduced the dollar-value of the funds budgeted for government export programmes. This made it necessary for the company to intervene directly to help some of its customers to restructure their financial arrangements or, when this proved impossible, to provide special price adjustments. Embraer has also become Brazil's biggest exporter, accounting for $3.5 \%$ of total Brazilian sales abroad in 1999. Although it buys roughly half of its inputs abroad, ${ }^{26}$ making it the country's second largest importer, it recorded a positive net balance of US\$ 984 million in January-November 2001. In 2001 Embraer made substantial gains by buying parts at the beginning of the year with a strong real and then selling whole planes later in the year with a dollar that gave more reais in return.

\section{The challenges ahead}

At the 1999 Paris air show Embraer announced it would build a new 70-108 seat platform, sharing approximately $80 \%$ of the existing components (but not the engine nor the wing design), which should nearly double its production volumes. Prior to the launch, Embraer held a number of advisory board meetings with potential customers, in order to incorporate their comments into the design of the aircraft. $^{27}$ The ERJ-170's maiden flight was on 19

\footnotetext{
26 “Embraer quer exportar US\$ 9bi até 2005”, Folha de S. Paulo, 5 November 2000.

${ }^{27}$ This input, for example, convinced Embraer to use two underwing engines, instead of the engines-on-the-tail design for the ERJ-145 and ERJ-135 series, thus simplifying aircraft servicing and boosting passenger comfort. This solution allows for full baggage and food loading on the side of the aircraft with its engine shut down. During ground servicing, the engine on the other side could continue to provide electrical power and air conditioning. This configuration should also help operators minimize turnaround times.
}

February 2002 and the first deliveries will take place in late 2002, while the larger model will be available in 2004. Switzerland's Crossair, the largest regional airline in Europe, will be the first to exploit the technological and marketing advantages (including a prestige factor) associated with operating a brand-new aircraft. ${ }^{28}$

The rapid increase in the backlog of orders presents substantial production challenges and, as the new family of aircraft enters into production, scheduling conflicts may emerge. Simply to deliver firmly-ordered planes (i.e., those for which a customer has made a contractual commitment accompanied by a down payment), ${ }^{29}$ Embraer had to increase its monthly production capacity by $33 \%$ in the course of 2000 (Embraer, 2000a, p. 14). Besides regional jets, Embraer is also involved in a number of projects in defence, aerospace and general aviation (table 2). Construction work has started on a US\$ 150 million manufacturing and test site at Gavião Peixoto, a remote (some 280 kilometres northwest of São Paulo) and fog-free location that will enable airworthiness flights of high-speed military aircraft to be carried out in Brazil, instead of sending the planes to the Lake Moses base in the United States.

In November 1999, Aérospatiale-Matra, Dassault Aviation and Thomson-CSF each acquired a 5.5\% stake in Embraer, and Snecma bought a further 3\%, so that the company's value rose to nearly US\$ 1 billion. The French shares will not carry voting rights, but they will receive a $10 \%$ higher dividend and will allow the new partners to appoint two directors to the 11-member board. The French consortium outbid rival proposals by BAe and Lockheed Martin, ${ }^{30}$ all anxious to clinch a deal to improve their chances of winning a possibly large order for the FX-BR modernization programme of the Brazilian Air Force, which is expected to demand that Embraer be given a key

\footnotetext{
${ }^{28}$ Crossair chose Embraer over competing propositions from Fairchild-Dornier and Bombardier. According to a report by United States trade officers based in Zurich, the principal factors in favour of the Brazilian jet were the overall weight, the cabin configuration (a single-aisle layout with a $2+2$ seat configuration, versus a single aisle with a $2+3$ seat configuration on the Fairchild jet), a certain amount of existing acceptance of the product, and an aggressive pricing policy (Galambos, 2000).

${ }^{29}$ For the sale of regional aircraft, Embraer customarily receives a deposit upon signing of the purchase agreement and three progress payments (each equivalent to $5 \%$ of the sales price) 18,12 and 6 months before scheduled delivery. The deposit and progress payments are generally non-refundable.

30 "BAe eyes 20pc stake in Embraer", The Daily Telegraph, 14 August 1999 .
} 
TABLE 2

Embraer's project portfolio (excluding regional jets)

\begin{tabular}{ll}
\hline Name & Description and production volumes \\
\hline AL-X & Developed under a contract with the Brazilian Air Force (FAB). Two prototypes have been flying since 1995. \\
& The maiden flight of the first pre-production aircraft took place in May 1999, and the first delivery was due in \\
& 2001. These aircraft, whose engine is twice as powerful as that of the standard Tucano, will be used for \\
& advanced pilot training and for defence operations in Amazonia.
\end{tabular}

AMX

The project resulted from 1977 Italian Air Force specifications for a small tactical fighter-bomber. Embraer joined the original Aeritalia/Aermacchi partnership in 1980. The first prototype flew in May 1984, production began in mid-1986, and the first aircraft of the 30-unit batch (21 for Italy, nine for Brazil) rolled out in Turin in March 1988. A second contract (Italy 59, Brazil 25) was signed in 1988 and production for the Brazilian Air Force started the following year. A third production lot was authorized in early 1992, with the first two-seater for the Brazilian Air Force delivered in May 1992.

AMX-T

An enhanced version of the AMX. Production began in Italy in late 1994, where it was halted in 1998 (after production of 110 single-seaters and 26 two-seaters), but it continues in Brazil. Approximately 190 aircraft are currently in operation in the Italian and Brazilian Air Forces. In September 1999 the AMX-T won a bid to supply Venezuela.

EMB-145 AEW\&C and RS

Special versions of the ERJ-145 unveiled in May 1999. The AEW\&C's advanced radar system, developed by Ericsson, has the capacity to carry out supervision, patrol and air traffic control missions. The RS was designed for remote surface measuring missions, environmental control and geological surveys. They are expected to play a key role in the US\$ 1.2 billion Amazon Surveillance System (SIVAM) being developed by Raytheon. The Greek Air Force has contracted Embraer to furnish four AEW\&Cs, to be used in its airspace advance warning and control system within the NATO environment. An ERJ 135 aircraft for special transport and support missions was acquired under this same contract. Mexico also selected Embraer to supply an AEW\&C and two RSs for maritime patrol duties.

EMB-314 Super Tucano

A single-engine turboprop aircraft used for pilot training and armed reconnaissance missions. Some 650 units of the first EMB 312 Tucano version have been produced and are in operation in 15 air forces around the world. Currently under development is the AL-X configuration (Light Attack Aircraft), equipped with a 1,600 SHP engine, advanced avionics and other technological advances, in both single- and twin-seat versions. In August 2001 the FAB signed a contract for 76 firm orders, with 23 additional options, to operate in basic/early advanced training missions, including weapons familiarization. Production started in February 2002.

International Space Station An international project involving 13 OECD countries, Russia, and Brazil, which is responsible for assembling a platform connected to the outside of the International Space Station for performing experiments. The Agência Espacial Brasileira, which coordinates the Programa Nacional de Atividades Espaciais (PNAE), selected Embraer, which works with Boeing.

Legacy

A modified version of the ERJ-135, produced in executive, corporate shuttle, and VIP configurations, unveiled at the 2000 Farnborough Air Show. With the addition of two more fuel tanks, the executive version has a range of 3,200 nautical miles, enough to fly coast-to-coast across the United States or from Paris to the Middle East. The maiden flight was in March 2001 and Brazilian certification was received. As at March 2002, Embraer had received 25 firm orders and 50 options.

Source: Prepared by the author on the basis of data from Embraer and other sources.

role in the deal. ${ }^{31}$ Embraer and the French industrialists are expected to jointly promote the Mirage 2000 and Rafale combat aircraft, as well as the turbofans and electronic software produced by Snecma and Thomson-CSF. ${ }^{32}$ This

\footnotetext{
${ }^{31}$ Between 75 and 150 aircraft will be needed before 2005 to replace aging F-5s and Mirages, for a total cost of as much as US\$ 6 billion. In August 1997 the Clinton administration cancelled a 20-year ban on sales of US high-technology weapons and aircraft to Latin America.
}

strategic alliance will increase Embraer's military aircraft sales, which currently account for $7 \%$ of total revenue,

${ }^{32}$ In April 2002 Embraer and its French partners established the "Mirage 2000 BR Consortium" to market a new version of the Dassault Aviation Mirage 2000-5 Mk 2 in Latin America. The activities of the new consortium, in all domains, will be co-ordinated by Embraer, which will exercise the role of consortium leader. Analysis, development and testing activities for the Mirage 2000 BR will be jointly performed, either at Embraer's facilities in Brazil, or in France. The final assembly line will be at Embraer's new plant at Gavião Peixoto. 
and its penetration into the Chinese market. ${ }^{33}$ The decision was disputed by the Air Force commanders, who were offended at not being consulted over the government's decision to back the deal and were concerned that Embraer's association with Dassault will oblige them to buy French equipment. Following particularly serious comments, the commander-in-chief was sacked by the government. ${ }^{34}$ The Brazilian attorney general ruled that the sale does not constitute a change of control and that, insofar as it does not weaken the country's national interests, the government should not use its golden share to block the deal.

\section{IV}

\section{Making sense of the evidence}

In the course of its 25-year history as a State-owned enterprise, Embraer used licensing and co-operation agreements to bring new resources and knowledge into the firm and develop a strong core competence-system engineering for producing aircraft. But while this learning process was initially accompanied by progress on other fronts -such as organizational and marketing skills- by the mid-1980s engineering considerations overtook other criteria in the minds of senior management. Linkages between different parts of the company -and a fortiori between Brazil and the foreign affiliates that were supposed to provide advance warning of what customers were demandingweakened. Writing in 1992, when Embraer was facing the most severe crisis in its short life, Frischtak acknowledged its ability to exploit a niche in the world market, but singled out the lack of financial resources and market-driven technical solutions as the main bottlenecks preventing it from sustaining this success over the long run. He also identified co-operative development, production, and marketing agreements as key actions to achieve recovery.

\section{Top management}

The post-privatization recovery owes a lot to the actions implemented by the new management, which injected a new corporate strategy to ensure alignment between Embraer's core competences and market signals. Various forms of organizational changes have led to innovations and improved performance. The hierarchy

\footnotetext{
${ }^{33}$ In September 2000 Sichuan Airline received the first of the four ERJ-145s which it had ordered. This is the first Embraer plane to operate in China and also the first Embraer jet in the Southeast Asian market. In 2002 Embraer inaugurated a warehouse at Beijing International Airport.
}

was flattened by cutting the number of managerial levels from ten to four, and performance-related remuneration was also introduced for all employees (Ghemawat, Herrero and Monteiro, 2000). Most importantly, a number of activities - such as strategic planning, total quality management, market intelligence, the kaizen workforce empowerment strategy, and the analysis of system performance feedback - were formalized and endogeneized in the company's routines (Bernardes, 2000a).

The process of organizational change involves "vision", learning by trial and feedback, and consensusbuilding (Fujimoto, 2000). All these elements have played a role, and although it is not easy to say how they rank, vision has probably been the most important. In 2001, Mauricio Botelho, Embraer's CEO since 1994, won the annual Laurels Award granted by the industry's leading magazine for "correctly reading the transformation of the commuter airline industry from turboprops to jets -an insight not gleaned by many established European and American manufacturers- and focusing on a single overarching objective: customer satisfaction" (Aviation Week and Space Technology, 2001). It is important to remember that at Embraer the formal creation of a market intelligence function came after, and not before, the launch of the ERJ family. Botelho, while a mechanical engineer by training, did not have any background in aerospace, and this may have it made it easier to spot the transformation that was taking place in the industry.

The TOR (Transforming the Organization for Results) Programme launched in 1997 stands at the core of the learning process. In a phase of rapid growth, it

\footnotetext{
34 The Embraer controversy coincided with the government's attempt to take the management of the country's airport system away from the air force, in view of the system's possible privatization. See "De cavalo a burro", Veja, 12 January 2000.
} 
has aimed at integrating the development of new activities with constant review and improvement of operational processes. TOR includes corporate initiatives such as Integrated Technological Development (in the areas of production, product engineering, and information technology), emergency projects, data cleaning, and implementation of the ERP (Enterprise Resource Planning) system. As regards the personal development and professional training of its workforce, Embraer has implemented a Career and Salary Plan, an Industrial Integration Programme, and a Supplementary Retirement Plan. In 2000, the medical, hospital and social benefits offered to employees totalled R\$ 124 million: an 81\% year-on-year increase. Finally, in 2000 the Profit Sharing Programme distributed R\$ 81 million, compared with $\mathrm{R} \$ 36.6$ million in 1999 (Embraer, 2000b).

\section{Location}

São José dos Campos stands in the very heart of the Paraíba Valley and consists of 43 municipalities that host 430 exporters and produce 3\% of Brazil's GDP. Multinational corporations such as Ericsson, Volkswagen, Ford and General Motors have established some of their largest plants worldwide here, and this has attracted additional investments in the component and electronics industries. Embraer was able to tap into these existing investments, playing the role of fulcrum and co-ordinator in a network of specialized Tier II suppliers (Bernardes, 2000b). While Embraer has not taken equity positions, some such firms were created in the mid-1990s by skilled technicians laid off by Embraer and other aerospace companies (table 3). A concerted effort to improve and deepen the articulation between different private and public partners is currently underway under the leadership of the São Paulo industrial federation (FIESP/CIESP), the national support programme for micro- and small enterprises of the Brazilian Enterprise Support Service (Serviço Brasileiro de Apoio às Empresas, Sebrae), and the local business associations (Associação Comercial e Industrial de São José dos Campos, ACI, and the Vale do Paraíba Chamber of Commerce). The ultimate goal of the Exporta Vale programme is to convert the region into Brazil's high-tech pole, with a strong presence of locally-groomed start-ups, and increase the number of exporting firms to 1,000 and the amount of foreign sales to US\$ 500 million by 2003 .

Research and development activities — such as mechanical analysis, thermal tests, electro-magnetic compatibility tests, and vacuum simulations - have been outsourced to the CTA. Within the framework of the Parceria para Inovação Tecnológica —Partnership for Technological Innovation (PITE) programme financed by FAPESP (Fundação de Amparo à Pesquisa do Estado de São Paulo- Research Support Foundation of the state of São Paulo) to enhance collaboration between business and the academic world, Embraer and ITA have also launched a number of projects (table 4). However, according to Bernardes (2000b), the links with this and other local technology institutions, such as the Escola de Engenharia de São Carlos and the Escola Politécnica, are becoming looser as Embraer increasingly resorts to foreign technological institutions ${ }^{35}$ and sets up its own technology schools to train personnel. The Engineering Specialization Programme in the field of Aeronautics, an initiative aimed at training newly graduated engineers and those with up to two years' experience, began in March 2001, and represents the first step towards establishing the Embraer Corporate University.

\section{Partners}

Several European and American aerospace component suppliers chipped in as risk-sharing partners for the ERJ-145, directly investing R \$ 64 million (of a total equal to R\$ 592.7 million, roughly US\$ 300 million) in cash and materials and providing liquidity via deferred payment provisions. First-tier suppliers (table 5) deliver whole systems -rather than discrete components- and take on the responsibility of managing the supply chain by sub-contracting discrete parts from lower-tier suppliers. In the case of the ERJ-170/190 family, development costs are even larger (about US\$ 850 million) and are by far the largest investment ever embarked upon by Embraer. No less than one-third of these costs will be contributed in cash by risk-sharing partners, who will be responsible for developing, producing, and delivering entire systems as well as major components. The whole process of selection and contracting of the main risk-sharing partners took a year from inception to completion. Requests for proposals were sent to 85 companies, of which 58 submitted tenders. Embraer will be responsible for the forward

\footnotetext{
35 Transonic wind tunnel tests are conducted at the NLR National Aerospace Laboratory in the Netherlands and low speed trials at the Central Aerohydrodynamics Institute of Russia (TsAGI). These tests are primarily oriented towards examining the wing's performance in various segments of its intended flight envelope.
} 
TABLE 3

Brazil: Some of the aerospace companies located in the Paraíba Valley

\begin{tabular}{|c|c|}
\hline Company & Description \\
\hline $\begin{array}{l}\text { AEROSERV Serviços } \\
\text { Aeronáuticos }\end{array}$ & $\begin{array}{l}\text { Established as a micro-enterprise in } 1999 \text {, operating inside the Embraer plant, it has rapidly become a small/ } \\
\text { medium-sized enterprise, with sales of US\$ } 5 \text { million in } 2001 \text {. It now has its own plant in Jacareí and } 200 \\
\text { employees, } 80 \% \text { of whom previously worked at Embraer. }\end{array}$ \\
\hline AKROS & $\begin{array}{l}\text { Founded in the early } 1990 \mathrm{~s} \text {, specializes in structural analysis and mechanical parts design, product engineering, } \\
\text { and manufacturing processes. It has also been active in the space programme, specifying dynamic and static } \\
\text { testing, doing structural analysis, developing mechanical tools design, as well as preparing and reviewing } \\
\text { technical documentation. }\end{array}$ \\
\hline CENIC & $\begin{array}{l}\text { Designs, produces and tests composite materials (carbon fibre) for mechanical parts and groups. Subcontractor } \\
\text { (composite motor cases, nozzle parts) for the VLS-1 (satellite launching vehicle) }\end{array}$ \\
\hline COMPSIS & $\begin{array}{l}\text { Established in } 1989 \text {, develops and produces numerically-controlled transport systems and testing devices for } \\
\text { the auto industry. Its product development and production technologies meet the DOD-STD-2167 and ANSI/IEEE } \\
\text { standards required for the acquisition, development or support of mission-critical software systems. }\end{array}$ \\
\hline DIGICON & $\begin{array}{l}\text { Started its activities in the area of transducers and processors for numerical control machinery. It also produces } \\
\text { plotters and hard disks, as well as some CAD software. Produces mechanical components of structural parts and } \\
\text { subsystems for satellites of INPE (National Space Research Institute) and assembles satellite solar panels, in } \\
\text { collaboration with Germany's MBB. }\end{array}$ \\
\hline ELEBRA & $\begin{array}{l}\text { Produces, sells and distributes electronic communications equipment and electronic parts (radars, air traffic } \\
\text { control consoles, antennae and high frequency transmitters) and provides industrial and civil engineering services. } \\
\text { It reported sales of US\$ } 15 \text { million in 1999. It has now been bought by the NORCAL Group. In the framework of } \\
\text { the CBERS (China-Brazil Earth Resources Satellite Cooperation) programme, it was responsible for the } \\
\text { development of the on-board computers, the attitude and orbit control systems, and the design of UHF transmitters. }\end{array}$ \\
\hline Gespi Aeronáutica & $\begin{array}{l}\text { Established in } 1974 \text { to design and manufacture parts and components for Embraer. Since 1990, its aerospace } \\
\text { division has developed other products, such as ground support equipment, aviation components cleaning } \\
\text { equipment, and anti-haze rocket systems. }\end{array}$ \\
\hline MECTRON & $\begin{array}{l}\text { Founded by ITA graduates, it develops defence systems such as simulators for anti-tank missiles, electronic } \\
\text { equipment for medical applications, and traffic control systems. In the aerospace field, it has developed electrical } \\
\text { systems, electronic components and satellite control software, as well as some data collecting platforms. In } \\
2001 \text { the Italian Air Force awarded Mectron and Alenia a US\$ } 45 \text { million contract to equip its fleet of AMX } \\
\text { aircraft with the SCP-01 radar. }\end{array}$ \\
\hline $\begin{array}{l}\text { N\&N Informática e } \\
\text { Automação }\end{array}$ & $\begin{array}{l}\text { Develops customized software for image processing, process control, and product line automation. Customers } \\
\text { include the Brazilian Air Force and Navy. }\end{array}$ \\
\hline Qualitas Engenharia & $\begin{array}{l}\text { Established in } 1993 \text { to develop management systems. Customers include Helibras and Embraer (development } \\
\text { of applications to simulate pre- and post-sale relations with clients and customer support systems). }\end{array}$ \\
\hline TECNASA & $\begin{array}{l}\text { Founded by ITA graduates, specializes in electronic equipment for air navigation support, such as multimode air } \\
\text { combat radar (for the AMX) and several countermeasures systems. For the MEC-B and CBERS projects, the company } \\
\text { developed telemetry and telecontrol transponders and has defined specifications for several items at its design } \\
\text { testing facilities. }\end{array}$ \\
\hline Tectelcom Aerospacial & Subsidiary of the Tectelcom group. \\
\hline
\end{tabular}

Source: Prepared by the author on the basis of company information and other sources.

fuselage, nose cone, centre fuselage II, and wing to fuselage fairings. Some foreign suppliers (such as Pilkington Aerospace, Parker Hanefin, and Sonaca) have already set up operations in Brazil, while others (such as Latécoère) are planning to do so (Gazeta Mercantil, 2000). Embraer also created ELEB, a joint venture with Germany's Liebherr, to produce landing gear and hydraulic components, which in November 2000 was merged with Órbita Sistemas Aeroespaciais.

This strategy should not only reduce Embraer's development costs and risks, but also, by reducing the number of its suppliers and easing logistics, allow it to 
TABLE 4

Brazil: Embraer joint projects financed by FAPESP

\begin{tabular}{|c|c|c|c|c|}
\hline & Partner & $\begin{array}{l}\text { Total budget } \\
\text { (US\$) }\end{array}$ & $\begin{array}{l}\text { Embraer share } \\
\text { (per cent) }\end{array}$ & Time frame \\
\hline $\begin{array}{l}\text { Development of a DGPS system for real time aircraft } \\
\text { positioning }\end{array}$ & INPE & 218,117 & 0 & $\begin{array}{l}\text { March 2002- } \\
\text { August } 2003\end{array}$ \\
\hline $\begin{array}{l}\text { Advanced applications of computational fluid } \\
\text { mechanics to high-performance aircraft }\end{array}$ & ITA & $1,255,000$ & 8 & $\begin{array}{l}\text { January } 2002- \\
\text { December } 2004\end{array}$ \\
\hline $\begin{array}{l}\text { Identification of aerospace stability and control } \\
\text { derivatives }\end{array}$ & ITA & 195,525 & 0 & $\begin{array}{l}\text { January } 2002- \\
\text { June } 2003\end{array}$ \\
\hline $\begin{array}{l}\text { Development of aerodynamics testing technology } \\
\text { for high-performance aircraft }\end{array}$ & ITA & 948,479 & 0 & $\begin{array}{l}\text { June } 2001- \\
\text { May } 2004\end{array}$ \\
\hline
\end{tabular}

Source: Fundação de Amparo a Pesquisa do Estado de São Paulo - Research Support Foundation of the State of São Paulo (FAPESP).

TABLE 5

Embraer's risk-sharing partners

\begin{tabular}{|c|c|c|}
\hline & ERJ $145-135$ & ERJ $170-190$ \\
\hline C\&D (United States) & Cabin and cargo compartment interiors & Interiors \\
\hline ENAER (Chile, State-owned) & $\begin{array}{l}\text { Vertical fin, horizontal stabilizers and } \\
\text { elevators }\end{array}$ & \\
\hline $\begin{array}{l}\text { GAMESA (Grupo Auxiliar Metalúrgico) } \\
\text { (Spain) }\end{array}$ & $\begin{array}{l}\text { Wings, engine nacelles and main } \\
\text { landing-gear doors }\end{array}$ & $\begin{array}{l}\text { Rear fuselage and the vertical and } \\
\text { horizontal tail surfaces }\end{array}$ \\
\hline General Electric (United States) & & Turbofans, power plants and engine nacelles \\
\hline Grimes Aerospace (United States) & & Exterior and cockpit lighting \\
\hline Hamilton Sundstrand (United States) & & $\begin{array}{l}\text { Tail core, auxiliary power unit, electrical } \\
\text { systems, and air management system }\end{array}$ \\
\hline Honeywell (United States) & & Avionics systems \\
\hline Kawasaki (Japan) & & $\begin{array}{l}\text { Wing stub, engine pylon, fixed landing and } \\
\text { trailing edge assemblies, flaps, spoilers, and } \\
\text { flight control surfaces of the wings }\end{array}$ \\
\hline Latécoère (France) & & Central fuselage sections \\
\hline Liebherr (Germany) & & Landing gear assemblies \\
\hline $\begin{array}{l}\text { SONACA (Société Nationale de Construction } \\
\text { Aérospatiale) (Belgium, State-owned) }\end{array}$ & $\begin{array}{l}\text { Portions of the central and rear fuselage, } \\
\text { service, main and baggage doors, and engine } \\
\text { pods }\end{array}$ & $\begin{array}{l}\text { Moving parts for the wing leading edges, } \\
\text { associated systems (actuators, de-icing gear), } \\
\text { panels and sub-assemblies of the central } \\
\text { fuselage section (including the wing } \\
\text { attachment) }\end{array}$ \\
\hline
\end{tabular}

Source: Prepared by the author on the basis of company information and other sources.

EMBRAER: FROM NATIONAL CHAMPION TO GLOBAL PLAYER - ANDREA GOLDSTEIN 
concentrate on what it does better, i.e., designing, assembling, marketing and servicing the final aircraft. ${ }^{36}$ The 38-month development schedule also aims at frontloading problem-solving measures and identifying interference problems that are very costly to solve if identified after the first full-scale assembly (Thomke and Fujimoto, 2000).${ }^{37}$ Engineers from the risk-sharing partners are sent to Brazil to work with their Embraer counterparts. The ERJ-190 Joint Definition Phase started in May 2001 with Kawasaki Heavy Industries, who will be responsible for manufacturing the wings. A new Virtual Reality Center, using virtual prototyping and large-scale visualization to reduce time-to-market for new aircraft, was also built. Embraer will use ENOVIAvpm (Virtual Product Model) and CATIA to generate digital mock-ups instead of physical models, and all Tier I suppliers have been asked to install these programmes in order to facilitate communication. The master electronic mock-up is centralized in Embraer's computers, and a new, dedicated EDI (Electronic Data Interchange) system, utilizing a safe satellite channel, has been set up for on-line updating of the data bank.

\section{Public policies}

Finally, public sector institutions such as the BNDES and FINEP (Financiadora de Estudos e Projetos - Finance Fund for Studies and Projects, part of the Ministry for Science and Technology) have actively supported this process, contributing $22 \%$ and $100 \%$ of the development costs of the ERJ-145/135 family and of the AL-X light-attack jet fighter, respectively. Embraer has also been the largest beneficiary of PDTI (Programa de Desenvolvimiento Tecnológico Industrial -Industrial Technology Development Programme), a programme of the Ministry for Science and Technology which provides fresh funding and tax holidays to innovating firms. ${ }^{38}$ A total of R $\$ 142$ million was assigned to Embraer in subsidies between 1993 and 2000. ${ }^{39}$

\footnotetext{
${ }^{36}$ Embraer's programme for integrated product development is described in Araujo and da Cruz (2000).

${ }^{37}$ For instance, the use of computational fluid dynamics, digital mockups and virtual reality made it possible to simulate the introduction of winglets on the ERJ-170. Embraer decided to fit them, as they improve fuel consumption and climb capability, as well as Hot \& High performance and obstacle clearance.

${ }^{38}$ For details of the functioning of the export promotion mechanism, see http://www.mct.gov.br/prog/empresa/pdti_pdta/default.htm.

39 Data obtained from http://www.mct.gov.br/prog/empresa/ pdti_pdta/pdti_res_20_12.htm.
}

Finamex (now BNDES-exim) allows BNDES to finance up to $100 \%$ of capital goods exports. ${ }^{40}$ The Programa de Estímulo às Exportações - Export Promotion Programme (Proex), managed by the Banco do Brasil, is an "interest rate equalization programme", which provides up to a $3.5 \%$ rebate on interest rates on loans to purchasers of exported Brazilian aircraft. Its aim is to offset the so-called Custo Brasil, i.e., the higher risk of doing business in the country due to a number of structural factors.

In this brutally competitive environment, the rivalry between Embraer and Bombardier has escalated from the enterprise to the national level. Table 6 summarizes the various stages in this dispute, which in May 2000 led the Canadian government to ask the WTO for permission to retaliate by taking compensatory measures and blocking US $\$ 3.3$ billion in goods and trade privileges over seven years -the largest trade confrontation Canada has engaged in, and one of the largest disputes in the history of the WTO. The Brazilian authorities maintained that the threat of sanctions "could make it difficult or even impossible for Brazil to seek alternatives which would prevent an irrational escalation of the dispute, with the capacity to set off counter-retaliations or other measures that would damage the economic and commercial relationship in different areas". Since then, new WTO decisions have favoured Brazil, and Canada has indicated it will comply with the February 2002 ruling. The conclusions of a related study (Goldstein and McGuire, 2002) consider that policy-makers' ideas about the goals of trade policy go a long way towards explaining why this dispute drags on. For Brazil, its place as a leader of the developing world acts as a rallying point for government and firms alike. For Canada, the belief in a rules-based trading regime has led it to strongly oppose all violations, while insecurity about its competitiveness has led to a variety of government schemes to support firms in advanced sectors like aerospace. The study also argues that the WTO process has actually made resolution of the dispute more difficult by making it too costly for firms and countries to comply with the costs of losing.

\footnotetext{
${ }^{40}$ At the end of March 2000, a little over half of the outstanding orders were financed through the BNDES-exim programme (Embraer, 2000a, p. 12).
} 
TABLE 6

Dispute between Brazil and Canada in the wTo on export credits for regional aircraft

\begin{tabular}{lll}
\hline Event & Date & Description \\
\hline January 1998 & $\begin{array}{l}\text { President Cardoso (Brazil) and Prime Minister Chrétien (Canada) } \\
\text { appoint Special Envoys to recommend ways to resolve the } \\
\text { dispute. }\end{array}$
\end{tabular}

Special Envoys' Report May 1998

Canada's request to the wTO

July 1998

Brazil's request to the wTO

July 1998

Appointment of panels

October 1998

DSB (Dispute Settlement Body) decision

March 1999

DSB decision

April 1999

Appellate body decisions

Brazil's status report

Canada's status report

Bilateral agreement

Compliance panel ruling

Appellate body decision

Arbitration panel decision

Interim decision

Interim ruling

DSB ruling
October 2001

August 1999

November 1999

November 1999

November 1999

May 2000

July 2000

August 2000

June 2001

February 2002
Recommendation that the two governments should negotiate, within two months, a bilateral accord.

To examine whether the "interest equalization" component of Proex constitutes a subsidy within the meaning of Article 1 of the ASCM (Agreement on Subsidies and Countervailing Measures) and whether such subsidies contravene Article 3 of said Agreement.

To examine export financing by the Export Development Corporation (EDC) and Industry Canada provided as support for research and development.

The European Union and the United States reserved their right to participate in both panel proceedings as third parties.

Brazil afforded Embraer an illegal subsidy and should withdraw it within 90 days.

Canada should withdraw without delay some subsidy programmes supporting Bombardier. There is not sufficient cause to pursue Brazil's complaints about sub market rate financing by the EDC any further.

Upheld the initial findings in both cases.

The interest rate equalization payments under Proex would be granted only to the extent that they would bring the net interest rate applicable to a transaction under that programme down to the appropriate international "benchmark" (and not below it, as had sometimes happened in the past).

The Canada Account financing of regional aircraft exports was discontinued immediately, and all existing obligations to disburse Technology Partnerships Canada (TPC) funds to that industry terminated.

Both countries filed notices requesting the reconvening of the original DSB panels to decide if the two countries have complied with the panel decisions.

Proex-based sales (affecting some 900 Embraer aircraft) cannot proceed.

Upheld the previous decision.

Canada is entitled to impose tariffs on Brazilian goods worth US\$ 230 million per year until a bilateral accord is reached.

The reformed Proex does not necessarily contravene international trade rules. In order for Brazil not to abuse the programme, financing must be at market rates plus a premium for risk; loans must be for no longer than 10 years; and the Proex loans must cover no more than 85 per cent of the purchase in question.

Canada asked for authorization to continue financing given to three separate Bombardier jet buyers (Air Wisconsin, Comair, and Air Nostrum).

The EDC's loan guarantees to three separate Bombardier jet buyers constituted a prohibited export subsidy and must be withdrawn within 90 days. 


\section{$\mathrm{V}$}

\section{Conclusions}

The transformation of Embraer has been described as "a saga from agony to glory" (Exame, 1999) and the company itself as a "scrappy, audacious and canny survivor" (The New York Times, 2000). Of course there are risks -in particular the heavy dependence on a small number of key customers (Continental Express, American Eagle and Crossair), the substantial amount of debt, and the results of entering into head-on competition with Airbus and Boeing in the bottom end of the full-size jet market- but the company appears to be in a strong position to resist most shocks.

Domestic and international circumstances obliged Brazil to change its approach to development. Privatization was one of these changes, and indeed it was the most important one in the case of Embraer, as the change of ownership forced it to adapt to the new scenario of rapid technological change, shorter product cycles, and shrinking public financial capabilities. Its success in an industry traditionally dominated by American and European producers shows that firms based in developing countries can adapt to changing circumstances and adverse conditions. To be successful in this, they must channel their resources into new valuegenerating activities through product development, the establishment of alliances, and strategic decisionmaking. Management skills must be seen as the ability to establish a network of linkages with various external groups in order to maximize the value of corporate resources.

How much continuity is there in this story? The company recovered after privatization because the new management introduced new forms of organizing design, production, financing and marketing and drastically reduced time-to-market. We should not forget, however, that the project for developing the ERJ-145, around which so much of Embraer's fortunes turns, started before the ownership transfer. The capacity to use alliances to bring new resources into the firm from external sources is undoubtedly another constant in the story of Embraer. Insofar as the company competes with bigger companies based in countries with a richer endowment of human capital and institutional infrastructure, Embraer necessarily had to base its development on the identification of a reduced number of core capabilities and their exploitation over time. But the change in the relative bargaining power is eye-catching. In the 1970s Embraer benefited from the willingness of foreign assemblers to license technology to a still minor industry participant in order to enter the Brazilian and other Southern markets. Two decades later, its partners are to be found among secondtier aero-parts suppliers -some of them from OECD countries- eager to count on Embraer's credibility in order to enter the world market. ${ }^{41}$ The recent French partnership is also innovative since it allows Embraer to integrate its own production capabilities with its allies' marketing skills in Asia and the defence market.

All the large and successful companies in the world share the conviction that they must match their global rivals in technology, productivity and entrepreneurial drive. Is Embraer, which is one of the few Latin American global players, any different? ${ }^{42}$ Not at first sight, as it is just as aggressive, technologically savvy, and outward-looking as any other fast-growing corporation. In other words, it seems intuitively true that, regardless of their national origin, only firms capable of making a good return on investment in manufacturing facilities, marketing systems, and modern management methods can be successful (Dosi, Nelson and Winter, 2000). At the same time, however, "countries and organizations approach development and globalization in different ways" (Guillén, 2000, p. 16). The argument is usually justified: it pays to be diverse. What is striking, then, is that Embraer has been obliged to internalize some functions which, in most parts of the world, are not considered to be the direct responsibility of corporations. Thus, Embraer was able to boast a fully literate workforce only in Christmas 1997, when almost 150 employees passed the Brazilian second-level school certificate after attending a special corporate programme (Bernardes, 2000a), and in 2002,

\footnotetext{
41 Sonaca and Enaer were only established in 1978 and 1981, respectively, and for the former the collaboration with Embraer accounts for $55 \%$ of its 2001 turnover. Gamesa created its aeronautics division to participate in the ERJ-145 project, which accounts for $90 \%$ of its turnover.

42 The arguments presented in this paragraph would be stronger if I had explicitly compared (at least) Embraer and Bombardier to analyse how they built up and exploited their organizational capabilities.
} 
the Instituto Embraer de Educação e Pesquisa (Embraer Educational and Research Institute) inaugurated a special school in São José dos Campos (the "Engineer Juarez Wanderley" high school).

Another special feature of Embraer is that, notwithstanding its substantial market share and satisfactory financial performance, it remains much smaller than its rivals such as Boeing, Airbus, and Bombardier (whose aerospace division is part of a much larger group). Size is important in an industry such as aerospace, where the ability to weather cyclical storms ensures that skilled personnel and expensive machinery are put to use even during a downturn (a problem Embraer already experienced in the early 1990s). The fact that the firm thrives as a stand-alone entity, rather than as a division of one of the diversified business groups that have traditionally dominated the corporate landscape in emerging markets, therefore reflects its ability to make the most of its resources.

Finally, there is another lesson that the Embraer story can teach policy-makers in industrializing countries. In its early phase as an infant player on the global commuter aircraft market, Embraer received government support through various instruments, including targeted technological promotion, financing and skill development. As non-economic objectives of national pride and prestige also played an important role, procurement decisions by the Ministry of Aeronautics were adapted to the long-term goal of enhancing indigenous technological accumulation. It is important to underline, however, that the government bodies supporting the company have changed rather dramatically in the 1990s. Whereas for many years the defenders of Embraer were mostly in the Air Force and in engineering circles, in the more recent past they are to be found in the BNDES national development bank and possibly, at Itamaraty, the Brazilian Ministry of Foreign Affairs. ${ }^{43}$ While in the past Brazilians were proud of a domestic company capable of making aircraft, nowadays they are even

43 The Brazilian government has proposed the launching of a Mercosur initiative to increase the size of the regional air transport market and is considering removing domestic levies that currently favour imported aircraft (O Estado de S. Paulo, 22 September 2000). more pleased that Embraer is able to make profits. The military, however, show a much higher degree of admiration for the successes of the Brazilian aerospace program and somewhat deride Embraer's export achievements by pointing to the high import content of its products. ${ }^{4}$

In conclusion, then, Embraer has been able to influence the structure of the world market for regional jets, notably through export subsidies but more generally through the support it received from the Brazilian government. Insofar as high tariff protection and local content requirements have not played a major role in Brazilian policy for the aeronautics industry, it has not been too difficult to keep in line with wTO rules. The main exception, of course, is in the area of export subsidies, although it should be emphasized that the Proex export promotion system is a broad-based instrument, not targeted to any specific sector. While it is true that a more determined effort at reducing policy inconsistencies on the supply side would have reduced the need for an interest rate equalization programme (Bora, Lloyd and Pangestu, 2000), it is unlikely that Embraer could have survived in the real world while waiting for Brazil to reach this stage of development. Obviously, a more rigorous analysis is needed to quantify the net results of Proex's aid, although the prima facie evidence is that it has allowed Embraer to be a price-maker in its market. A similar reasoning applies to the financing provided by BNDES, which proved crucial in supporting the management in the recovery phase, before Embraer gained access to the New York Stock Exchange. A more immediate lesson from the Brazil-Canada WTO saga, albeit perhaps one devoid of normative value, is that non-OECD countries are probably more easily caught out when practising strategic trade policies - possibly because they do not sit at the table where the negotiations to regulate export subsidies take place.

(Original: English) ${ }^{44}$ Interview with the Director-General of the Air Force's R\&D
department (in Tecnologia \& Defesa, 1999). 


\section{Bibliography}

Araujo, C. and J. L. Da Cruz (2000): A view of the practice of integrated product development at EMBRAER, paper presented at the $5^{\text {th }}$ International Seminar on High Technology, Piracicaba, 5 October, mimeo.

Aviation Week and Space Technology (2001): 2000 Laurels awards, 7 May.

Baldwin, R. and H. Flam (1989): Strategic trade policies in the market for 30-40 seat commuter aircraft, Weltwirtschaftliches Archiv, No. 125, Tübingen, J.C.B. Mohr.

Bernardes, R. (2000a): EMBRAER. Elos entre Estado e mercado, São Paulo, Hucitec.

(2000b): $O$ arranjo produtivo da EMBRAER na região de São José dos Campos, paper presented at the International Seminar "Arranjos e Sistemas Produtivos Locais e as Novas Políticas de Desenvolvimento Industrial e Tecnológico", Rio de Janeiro, 4 - 5 September, mimeo.

Bora, B., P. Lloyd and M. Pangestu (2000): Industrial policy and the WTO, World Economy, vol. 23, No. 4, Oxford, U.K., Blackwell Publishers.

Broinizi Pereira, M. (1991): Tiro pela culatra, in Fundação Perseu Abramo, Teoria \& debate, No. 14.

Busch, M. (1999): Trade Warriors. States, Firms, and StrategicTrade Policy in High-Technology Competition, Cambridge, Massachusetts, Cambridge University Press.

Business Week (1996): EMBRAER's little jet could circle the globe, U.S.A., McGraw-Hill Companies, Inc., 28 October.

Campolina Diniz, C. and M. Razavi (1999): São José dos Campos and Campinas, in A. Markusen, Y. S. Lee and S. DiGiovanna (eds.), Second Tier Cities, Minneapolis, University of Minnesota Press.

Chandler, A., F. Amatori and T. Hikino (1997): Big Business and the Wealth of Nations, Cambridge, Massachusetts, Cambridge University Press.

Dagnino, R. (1993): Competitividade da indústria aeronáutica, Brasilia, Ministry of Science and Technology / Finance Fund for Studies and Projects (FINEP)/Programa de Apoio ao Desenvolvimento Científico e Tecnológico (PADCT).

Dahlman, C. and C. Frischtak (1993): National systems supporting technical advance in industry: The Brazilian experience, in R. Nelson (ed.), National Innovation Systems, Oxford, U.K., Oxford University Press.

Dosi, G., R. Nelson, and S. Winter (2000): Introduction: The Nature and Dynamics of Organizational Capabilities, in G. Dosi, R. Nelson, and S. Winter (eds.), The Nature and Dynamics of Organizational Capabilities, Oxford, U.K., Oxford University Press.

EMBraer (Brazilian Aircraft Corporation) (2000a): Prospectus, São João dos Campos, Brazil.

(2000b): Balanço Social, São João dos Campos, Brazil.

Evans, P. (1979): Dependent Development, Princeton, New Jersey, Princeton University Press.

Exame (1999): Decolou!, 30 June.

Financial Times (2000): Regional jet market gains altitude over bigger rivals, London, 17 April.

Folha de S. Paulo (2000): Embraer quer exportar US\$ 9bi até 2005, São Paulo, 5 November (www.folha.vol.com.br/folha).

Frischtak, C. (1992): Learning, Technical Progress and Competitiveness in the Commuter Aircraft Industry: An Analysis of Embraer, Industry series paper, No. 58,
Washington, D.C., World Bank, Industry and Energy Department (IEN).

Fujimoto, T. (2000): Evolution of manufacturing capabilities and ex post dynamic capabilities: A case of Toyota's final assembly operations, in G. Dosi, R. Nelson, and S. Winter (eds.), The Nature and Dynamics of Organizational Capabilities, Oxford, U.K., Oxford University Press.

Galambos, S. (2000): Regional/business aircraft and parts: Switzerland, Industry Sector Analysis Series, Washington, D.C., U.S. Commercial Service and U.S. Department of State.

Gazeta Mercantil (2000): Fornecedores da Embraer abrem fábricas no país, 8 November (www. investnews.net).

Ghemawat, P., G. Herrero and L. Monteiro (2000): EMBRAER: The global leader in regional jets, Harvard Business School Case Studies, Working paper, No. N9-701-006, Boston, Massachusetts, Harvard Business School Press.

Goldberg, P. and G. Maggi (1999): Protection for sale: An empirical investigation, The American Economic Review, vol. 89, No. 6, Nashville, Tennessee, American Economic Association.

Goldstein, A. and S. McGuire (2002): The political economy of strategic trade policy and the Brazil-Canada export subsidies saga, Paris, Organisation for Economic Co-operation and Development (OECD), Development Centre, mimeo.

Guillén, M. (2000): Diversity in Globalization. Organizational Change in Argentina, South Korea and Spain, Occasional papers, No. 6, Princeton, New Jersey, Princeton University, School of Social Science.

O Estado de S.Paulo (2000): Maciel sugere que Embraer cresça no Mercosul, São Paulo, 22 September.

Ramamurti, R. (1987): State-Owned Enterprises in High Technology Industries, New York, Praeger.

Sbragia, R. and J. Terra (1993): EMBRAER: trajetória de uma empresa de alta tecnologia brasileira, Cadernos de gestão tecnológica, No.8, São Paulo, Science and Technology Policy and Management Unit (NPGCT)/ University of São Paulo.

Sikkink, K. (1991): Ideas and Institutions: Developmentalism in Brazil and Argentina, New York, Cornell University Press.

Silva, O. (1998): A decolagem de um sonho. A história da criação da EMBRAER, São Paulo, Lemos.

Solingen, E. (1993): Macropolitical consensus and lateral autonomy in industrial policy: The nuclear sector in Brazil and Argentina, International Organization, vol. 47, No. 2, Cambridge, Massachusetts, The MIT Press.

(1998): Growth and decline of the military-industrial complex: The cases of Argentina and Brazil, International Politics, vol. 35, No. 1.

Tecnologia \& Defesa (1999): Dificil criar: fácil de desaparecer, No. 82, São Paulo.

The Daily Telegraph (1999): BAe eyes 20pc stake in Embraer, U.K., 14 August (www.dailytelegraph.co.uk).

The New York Times (2000): Brazil's hot commodity? Not coffee or soccer, New York, 31 December.

Thomke, S. and T. Fujimoto (2000): The effect of 'front-loading' problem-solving on product development performance, Journal of Product Innovation Management, vol. 17, No. 1.

Trebat, T. J. (1983): Brazil's State-Owned Enterprises: A Case Study of the State as Entrepreneur, Cambridge, Massachusetts, Cambridge University Press.

Veja (2000): De cavalo a burro, 12 January. 